\title{
Gastric-Type Epithelial Differentiation
}

National Cancer Institute

\section{Source}

National Cancer Institute. Gastric-Type Epithelial Differentiation. NCI Thesaurus. Code C95774.

A morphologic finding indicating the presence of gastric epithelial cell differentiation in a tissue sample. 